\title{
PENGARUH CARA PENGOLAHAN TEPUNG IKAN DARI LIMBAH INDUSTRI PENGOLAHAN IKAN NILA TERHADAP ENERGI METABOLISME DAN RETENSI NITROGEN PADA AYAM
}

\author{
(Influence Processing Of Tilapia Fish Industry By Product Meal \\ On Metabolisable Energy and Nitrogen Retention On Chicken)
}

\author{
Jonathan A Lase', Ma'ruf Tafsin², dan Nurzainah Ginting ${ }^{2}$ \\ 1. Mahasiswa Program Studi Peternakan Fakultas Pertanian Universitas Sumatera Utara \\ 2. Staf Pengajar Program Studi Peternakan Fakultas Pertanian Universitas Sumatera Utara
}

\begin{abstract}
The research aimed to study the influence of tilapia fish processing industry by product meal (LIPIN) on metabolisable energy and nitrogen retention on local chicken. The design in this research used completely randomized design with 6 treatments and 4 replications. The treatments consists of : commercial fish meal $\left(R_{0}\right)$, LIPIN meal pressed and drying with oven $40{ }^{\circ} C\left(R_{1}\right)$ and sundryng $\left(R_{2}\right)$, LIPIN non pressed and drying with oven $40{ }^{\circ} \mathrm{C}\left(R_{3}\right)$, non pressed and drying with sun $\left(R_{4}\right)$ and fermentation silage $\left(R_{5}\right)$. Variable were observed : nitrogen retention $(R N)$, metabolisable energy $(E M)$ and energy conversion. Commercial fish meal showed higher RN and energy conversion, but lower EM than LIPIN. Processed with pressed showed RN, EM and energy conversion lower than without pressed. Drying with oven showed higher EM, but lower RN and energy conversion than the sundryng. LIPIN fish meal showed RN, EM and energy conversion lower than silage fermentation. Commercial fish meal showed RN and energy conversion higher but lower EM than silage fermentation. It is concluded : that tilapia fish by product potential to replace commercial fish meal as chicken feed.
\end{abstract}

Keywords : Processing, Oreochormis niloticus, Nitrogen Retention, Metabolisable Energy, Local Chicken.

\begin{abstract}
ABSTRAK
Penelitian ini bertujuan mengetahui pengaruh cara pengolahan tepung ikan dari limbah industri pengolahan ikan nila (LIPIN) terhadap energi metabolisme dan retensi nitrogen pada ayam kampung. Rancangan yang dipakai dalam penelitian ini adalah rancangan acak lengkap dengan 6 perlakuan dan 4 ulangan. Perlakuan penelitian terdiri dari : tepung ikan komersial $\left(\mathrm{R}_{0}\right)$, tepung ikan dipres dengan pengeringan oven $40^{\circ} \mathrm{C}\left(\mathrm{R}_{1}\right)$ dan matahari $\left(\mathrm{R}_{2}\right)$, tanpa dipres oven $40^{\circ} \mathrm{C}\left(\mathrm{R}_{3}\right)$, tanpa dipres matahari $\left(\mathrm{R}_{4}\right)$ dan silase fermentasi $\left(\mathrm{R}_{5}\right)$. Parameter yang diamati dalam penelitian ini : retensi nitrogen $(\mathrm{RN})$, energi metabolisme $(\mathrm{EM})$ dan konversi energi. Tepung ikan komersial menunjukan hasil retensi nitrogen dan konversi energi lebih tinggi, tetapi energi metabolisme lebih rendah dibandingkan dengan LIPIN. Tepung ikan dipres menunjukan hasil retensi nitrogen, energi metabolisme dan konversi energi lebih rendah dibandingkan dengan tepung ikan tanpa dipres. Tepung ikan pengeringan oven dipres dan tanpa dipres, menunjukan hasil energi metabolisme lebih tinggi tetapi retensi nitrogen dan konversi energi lebih rendah dibandingkan dengan tepung ikan pengeringan matahari dipres dan tanpa dipres. Tepung ikan LIPIN menunjukan hasil retensi nitrogen energi metabolisme dan konversi energi lebih rendah dibandingkan dengan silase fermentasi. Tepung ikan komersial menunjukan hasil retensi nitrogen dan konversi energi lebih tinggi tetapi energi metabolisme lebih rendah dibandingkan dengan silase fermentasi. Kesimpulan penelitian ini : limbah industri pengolahan ikan nila (LIPIN) potensial digunakan untuk menggantikan tepung ikan komersial sebagai pakan ternak ayam kampung.
\end{abstract}

Kata kunci : Pengolahan, Oreochormis niloticus, Retensi Nitrogen, Energi Metabolisme, Ayam Kampung. 


\section{PENDAHULUAN}

Usaha ternak unggas khususnya peternakan ayam kampung merupakan salah satu sektor usaha yang memiliki peranan penting dalam memenuhi kebutuhan masyarakat akan protein hewani. Ayam buras merupakan sumber penghasilan yang cukup menjanjikan. Tak heran jika makin hari makin banyak orang yang tertarik memeliharanya.

Di dalam menyusun pakan ternak ayam kampung selalu berpatokan dalam imbangan protein dan energi. Menurut sumbernya protein dalam pakan ayam kampung dibedakan menjadi dua, yaitu : protein hewani dan protein nabati (protein dari tanaman atau sisa tanaman). Secara umum sumber protein hewani dalam pakan ayam kampung dipenuhi dengan penambahan tepung ikan di dalam formula ransum.

Tepung ikan merupakan bahan makanan ternak yang berkadar protein tinggi, mudah dicerna dan kaya akan asam amino essensial terutama lisin dan metionin sehingga dapat digunakan sebagai penutup kekurangan yang terdapat pada bii-bijian. Disamping itu tepung ikan kaya akan vitamin B, mineral dan kandungan lemak yang cukup juga merupakan sumbangan dalam memenuhi kebutuhan ternak akan energi (metabolis) dan juga vitamin yang larut dalam lemak yaitu vitamin A dan D.

Permintaan masyarakat terhadap pakan tepung ikan yang cenderung semakin tinggi berpengaruh terhadap produksi pakan yang berasal dari tepung ikan, namun permintaan ini masih bertumpu pada produksi pakan tepung ikan komersial. Penurunan produksi tepung ikan dan meningkatnya permintaan akan tepung ikan menyebabkan terjadinya peningkatan harga tepung ikan secara signifikan. Kita ketahui bahwa tepung ikan komersial di pasaran berada pada kisaran harga yang cukup tinggi. Tepung ikan ini terus meningkat harganya. Pasalnya di Indonesia tepung ikan merupakan bahan yang diimpor dari luar negeri seperti Thailand, Brasil dan Chili. Untuk menyiasati masalah ini sangat perlu tentunya pemanfaatan limbah, misalnya pemanfaatan tepung ikan dari limbah industri pengolahan ikan nila (LIPIN) yang selama ini di Indonesia tidak begitu diperhatikan padahal sangat potensial untuk dimanfaatkan sebagai pakan ternak.

Tepung ikan yang berasal dari limbah industri pengolahan ikan nila (LIPIN) sangat potensial dan efektif dijadikan pakan dengan berbagai perlakuan atau metode pengolahan untuk ayam kampung. Tepung ikan jenis ini tidak susah untuk mendapatkannya, bisa juga didapatkan dari limbah-limbah atau sisa dari industri keluarga. Kelebihan pakan dari tepung ikan sudah jelas berkadar protein tinggi, mudah dicerna dan kaya akan asam amino essensial 
terutama lisin dan metionin sehingga dapat digunakan sebagai penutup kekurangan yang terdapat pada bii-bijian.

Tepung ikan bukan berarti ikan utuh dikeringkan lalu digiling. Sebagaimana dikemukakan bahwa bagian yang utama untuk konsumsi manusia dan untuk ternak diambil sisa dari industri pengolahan ikan atau kelebihan hasil tangkapan. Oleh karena itu tepung ikan ini berasal dari berbagai ragam jenis varietas ikan sehingga beragam pula kandungan nutrisinya. Selain itu cara pengolahan tepung ikan juga memberikan pengaruh terhadap nutrisi tepung ikan.

Tepung ikan merupakan salah satu bahan baku sumber protein hewani dan mineral yang dibutuhkan dalam komposisi makanan ternak. Tepung ikan adalah produk berkadar air rendah yang diperoleh dari penggilingan ikan. Kandungan proteinnya relatif tinggi tersusun oleh asam-asam amino esensial yang kompleks (methionin dan lysin) dan mineral (Ca dan $\mathrm{P}$, serta vitamin B12). Bahan yang digunakan yaitu ikan, dan biasanya berbagai jenis ikan laut dapat diolah menjadi tepung ikan, akan tetapi yang paling ekonomis adalah ikan-ikan kecil (rucah) yang kurang disukai untuk dikonsumsi dan harganya relatif murah (Boniran, 1999).

\section{BAHAN DAN METODE PENELITIAN}

\section{Tempat dan Waktu Penelitian}

Penelitian dilaksanakan di Compost Centre Program Studi Peternakan Fakultas Pertanian Universitas Sumatera Utara, J1. Dr. A. Sofyan No. 3 Medan. Penelitian ini dilaksanakan selama 3 bulan dimulai Juli 2013 sampai dengan Oktober 2013, dimana lama penelitian ini dihitung dari mulai persiapan kandang sampai pengambilan sampel untuk dianalisis di laboratorium.

\section{Bahan dan Alat Penelitian}

Ayam kampung umur 12 minggu sebanyak 27 ekor sebagai objek penelitian, limbah industri pengolahan ikan nila sebagai perlakuan dimana limbah diperoleh dari PT. Aqua Farm. Bahan fermentasi berupa tetes tebu dan bakteri asam laktat dalam pembuatan perlakuan silase tepung ikan.

Kandang biologis ayam kampung yang mempunyai ukuran $\mathrm{p}$ x 1 x t $=52 \times 25 \times$ $45 \mathrm{~cm}$ sebanyak 27 petak, masing-masing kandang terdiri dari 1 ekor ayam kampung. Tempat air minum serta plastik penampung ekskreta, rodalon untuk mencuci tempat air minum, timbangan digital ohause dengan skala $2 \mathrm{~kg}$ dengan ketelitian $2 \mathrm{~g}$, oven $40^{\circ} \mathrm{C}$, label penanda 
kandang, sendok dan kantong plastik. Alat penerangan berupa lampu pijar sebanyak 25 buah. Termometer untuk mengetahui suhu, terpal dengan ukuran $\pm 3 \times 6$ m sebanyak 4 buah sebagai penutup dinding ruangan (kandang) dan peralatan kebersihan kandang.

\section{Metode Penelitian}

Rancangan acak lengkap (RAL) merupakan rancangan yang digunakan dalam penelitian ini. Penelitian ini menggunakan 6 perlakuan dan 4 ulangan. Perbedaan dari masing-masing perlakuan terletak pada cara pengeringan dan pengepresan tepung ikan serta dengan perlakuan silase tepung ikan fermentasi.

Perlakuan yang diteliti :

R0 = tepung ikan komersil

$\mathrm{R} 1=$ tepung ikan (dipres) dengan pengeringan oven $40^{\circ} \mathrm{C}$

$\mathrm{R} 2$ = tepung ikan (dipres) dengan pengeringan matahari

$\mathrm{R} 3=$ tepung ikan (tanpa dipres) dengan pengeringan oven $40^{\circ} \mathrm{C}$

$\mathrm{R} 4$ = tepung ikan (tanpa dipres) dengan pengeringan matahari

R5 = tepung ikan dengan silase fermentasi

Model matematik untuk rancangan acak lengkap yang digunakan dalam penelitian ini adalah

$$
\mathbf{Y}_{\mathrm{ij}}=\mu+\mathbf{T}_{\mathrm{i}}+\varepsilon_{\mathrm{ij}}
$$

Keterangan :

$\mathrm{i}=1,2,3, \ldots \mathrm{i}$ (perlakuan)

$\mathrm{j} \quad=1,2,3, \ldots \mathrm{j}$ (ulangan)

$\mathrm{Y}_{\mathrm{ij}}=$ respon atau nilai pengamatan dari perlakuan ke-i dan ulangan ke-j

$\mu=$ nilai tengah umum

$\gamma \mathrm{i}=$ pengaruh perlakuan ke-i

$\varepsilon_{\mathrm{ij}} \quad=\quad$ efek $\mathrm{j}$ galat pada perlakuan ke-i, ulangan ke- $\mathrm{j}$

(Sastrosupadi, 2002).

\section{Analisis Data}

Data yang diperoleh selama penelitian dari setiap perlakuan dianalisis dengan setiap pembandingan linier ortogonal kontras sehingga diperoleh informasi perlakuan yang terbaik. Dari 6 perlakuan dapat disusun 5 pembandingan linier ortogonal kontras sebagai berikut : 
Tabel 1. Perbandingan linier ortogonal kontras dari setiap perlakuan :

\begin{tabular}{|c|c|}
\hline Perlakuan & Keterangan \\
\hline $\mathrm{R}_{0} \mathrm{VS} \mathrm{R}_{12345}$ & $\begin{array}{l}\text { Tepung ikan komersial dibandingkan dengan tepung ikan } \\
\text { dari limbah pengolahan ikan nila dengan berbagai metode } \\
\text { pengolahan dan silase fermentasi }\end{array}$ \\
\hline $\mathrm{R}_{12} \mathrm{VS} \mathrm{R}_{34}$ & $\begin{array}{l}\text { Tepung ikan dari limbah ikan nila dengan metode } \\
\text { pengepresan kering oven dan kering matahari dibandingkan } \\
\text { dengan tepung ikan dari limbah ikan nila metode tanpa } \\
\text { dipres kering oven dan kering matahari }\end{array}$ \\
\hline $\mathrm{R}_{13} \mathrm{VS} \mathrm{R}_{24}$ & $\begin{array}{l}\text { Tepung ikan dari limbah ikan nila dengan metode kering } \\
\text { oven dipres maupun tanpa dipres dibandingkan dengan } \\
\text { tepung ikan dari limbah ikan nila metode kering matahari } \\
\text { dengan dipres dan tanpa dipres }\end{array}$ \\
\hline $\mathrm{R}_{1234} \mathrm{VS} \mathrm{R}_{5}$ & $\begin{array}{l}\text { Tepung ikan dari limbah ikan nila dengan metode oven } \\
\text { dipres, matahari dipres, oven tanpa dipres dan matahari } \\
\text { tanpa dipres dibandingkan dengan tepung ikan dengan } \\
\text { perlakuan silase fermentasi }\end{array}$ \\
\hline $\mathrm{R}_{0} \mathrm{VS} \mathrm{R}_{5}$ & $\begin{array}{l}\text { Tepung Ikan komersial dibandingkan dengan tepung ikan } \\
\text { dengan perlakuan silase fermentasi }\end{array}$ \\
\hline
\end{tabular}

\section{Parameter Penelitian}

\section{Retensi Nitrogen (\%)}

Retensi nitrogen diperoleh dengan melakukan pengukuran protein kasar tepung ikan, endogenous dan ekskreta ayam kampung. Retensi nitrogen menunjukkan nilai nitrogen yang digunakan oleh tubuh ternak. Nilai ini dapat diperoleh dari selisih antara nilai konsumsi protein kasar (KP) dengan nilai protein yang diekskresikan (EP) setelah dikoreksi dengan nilai ekskresi protein endogenous (ENP). Dengan kata lain retensi nitrogen (RN) yaitu selisih antara nilai konsumsi protein kasar dengan nilai protein kasar yang diekskresikan setelah dikoreksi dengan nilai ekskresi protein endogenous (Sibbald, 1980).

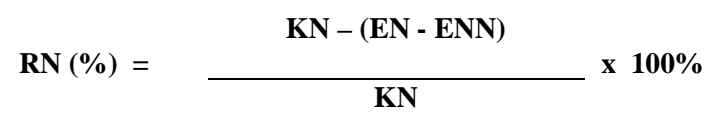

Keterangan :

$\mathrm{KN}$ : Konsumsi nitrogen (g/ekor)

EN : Ekskresi nitrogen (g/ekor)

ENN : Endogenous nitrogen (g/ekor)

\section{Energi Metabolisme (kkal/kg)}

Energi metabolisme adalah selisih antara kandungan energi bruto tepung ikan dengan energi bruto yang hilang melalui ekskreta. Energi metabolisme dinyatakan dengan 4 peubah (Sibbald dan Wolynetz, 1985) yaitu : 
a. Energi Metabolisme Semu (EMS) (kkal/kg) :

b. Energi Metabolisme Murni (EMM) (kkal/kg)

$$
\text { EMS }=\frac{(\text { EB x X })-(\text { Ebe } \times \text { Y })}{X}
$$

$$
\mathbf{E M M}=\frac{(\text { EB x X) }-[\text { Ebe } \times \text { Y })-(\text { Ebk } \times \text { Z })]}{\mathbf{X}}
$$

c. Energi Metabolisme Semu Terkoreksi Nitrogen (EMSn) (kkal/kg)

$$
\text { EMSn }=\frac{(\text { Eb } \times \text { X) }-[(\text { Ebe } \times \text { Y })+(8.22 \times \text { RN })]}{X}
$$

d. Energi Metabolisme Murni Terkoreksi Nitrogen (EMMn (kkal/kg)

$$
\mathbf{E M M n}=
$$

$($ EB x X $)-[($ Ebe $\times$ Y $)-($ Ebk x Z $)+(8.22 \times$ RN $)]$

Keterangan :

EB : Energi bruto tepung ikan $(\mathrm{kkal} / \mathrm{kg})$

Ebe : Energi bruto ekskreta $(\mathrm{kkal} / \mathrm{kg})$

Ebk : Energi bruto endogenous $(\mathrm{kkal} / \mathrm{kg})$

$\mathrm{X}$ : Konsumsi tepung ikan (gram)

Y : Berat ekskreta ayam yang diberi tepung ikan (gram)

$\mathrm{Z}$ : Berat ekskreta ayam yang dipuasakan (gram)

$\mathrm{RN}$ : Retensi nitrogen (gram)

8,22 : Nilai yang terkoreksi sebagai asam urat $(\mathrm{kkal} / \mathrm{kg})$

(Sibbald, 1980)

\section{Konversi EMSn/EB}

Total kandungan energi metabolisme bukan ditentukan oleh nilai energi metabolisme baik semu (EMS), murni (EMM), semu terkoreksi nitrogen (EMSn) ataupun murni terkoreksi nitrogen (EMMn), akan tetapi ditentukan oleh konversi EMSn terhadap energi bruto atau rasio $\mathrm{EM} / \mathrm{EB}$ ransum.

Keterangan :

$$
\mathbf{E M S n} / \mathbf{E B}=\frac{\mathbf{E M S n}}{\mathrm{EB}}
$$

EMSn : Energi metabolisme semu terkoreksi nitrogen $(\mathrm{kkal} / \mathrm{kg})$

EB : Energi bruto tepung ikan (kkal/ $/ \mathrm{kg})$

(Sibbald, 1980)

\section{Pembuatan Silase Fermentasi}

Perlakuan silase dalam penelitian ini berasal dari ikan nila utuh yang dicincang kecil kemudian dilakukan metode fermentasi (silase biologi). Bahan fermentasi yang digunakan berupa bahan yang kaya akan karbohidrat sebagai sumber energi bagi pertumbuhan bakteri. Bakteri tersebut akan memfermentasikan gula sehingga terbentuk asam laktat yang dapat menurunkan nila $\mathrm{pH}$ yang berfungsi sebagai bahan pengawet silase ikan tersebut. Bahan fermentasi yang digunakan dalam penelitian ini yakni bahan baku ikan nila, susu murni biokul plain dengan perbandingan ikan banding biokul plain 1:0,1 dan dedak 30 g sebagai sumber makanan untuk bakteri.

Langkah-langkah pembuatan silase fermentasi adalah : 
1. Langkah pertama yang dilakukan adalah dengan mencuci ikan yang digunakan sebagai bahan baku, dengan tujuan untuk membersihkan ikan dari kotoran dan benda keras yang mungkin terdapat pada ikan terutama karena bahan baku ikan didapatkan dari limbah, kemudian ikan dicincang ukuran 1-2 cm. Setelah dicincang sesuai ukuran, kemudian digiling dengan alat grinder (penggiling).

2. Ikan yang telah digiling halus kemudian dimasukkan kedalam wadah (ember) yang bersih untuk melakukan fermentasi.

3. Tambahkan susu biokul plain kemudian ditabur dengan dedak, diaduk rata kemudian dibungkus dengan kantong plastik dengan sifat anaerob.

4. Disimpan kemudian dibolak-balik selang 3 hari untuk mengatur kelembaban ikan yang difermentasi selama 14 hari fermentasi.

\section{Metode Pemberian Perlakuan Secara Paksa (Force Feeding)}

Metode pemberian perlakuan secara paksa dilakukan dengan menerapkan metode Sibbald dan Wolynetz (1985). Pada saat percobaan dimulai, digunakan 24 ekor ayam ditambah 3 ekor koreksi yang dipuasakan selama 24 jam. Perlakuan diberikan secara paksa sebanyak 24 g/ekor dengan bantuan corong (dicekok) setelah siap masa dipuasakan.Setelah 24 jam pemberian perlakuan, ekskreta dikumpulkan dan penanganan berikutnya sama halnya seperti pada teknik pemberian pakan tanpa paksa.

\section{Prosedur Pengambilan/Pengolahan Data}

1. Berat Ekskreta (g/ekor)

Berat ekskreta diperoleh setelah ekskreta dikeringkan dalam oven $40^{\circ} \mathrm{C}$.

2. Energi Bruto Ekskreta/EB (kkal/kg)

Energi bruto ekskreta diperoleh dari analisis energi menggunakan bomb kalorimeter.

3. Konsumsi Protein Kasar/KP (g/ekor)

Konsumsi protein kasar merupakan hasil perkalian dari jumlah ransum yang dikonsumsi (K) dengan kandungan protein kasarnya (PK).

4. Protein Kasar Ekskreta/EP (g/ekor)

Nitrogen ekskreta diperoleh dari analisis protein kasar laboratorium.

5. Protein Kasar Endogenous/ENP (g/ekor)

Protein kasar endogenous diperoleh dari analisis protein kasar laboratorium. 


\section{HASIL DAN PEMBAHASAN}

\section{Retensi Nitrogen}

Retensi nitrogen diperoleh dengan melakukan pengukuran protein kasar tepung ikan, endogenous dan ekskreta ayam kampung. Retensi nitrogen menunjukkan nilai nitrogen yang digunakan oleh tubuh ternak. Perbedaan cara pengolahan tepung ikan dari limbah industri pengolahan ikan nila dapat menyebabkan perbedaan nitrogen yang diretensi sehingga menghasilkan perbedaan dalam nilai energi metabolis. Rataan retensi nitrogen tepung ikan disajikan pada Tabel2.

Hasil rataan retensi nitrogen tertinggi pada perlakuan $\mathrm{R}_{0}$ sebesar $83,3691 \%$ dan rataan retensi nitrogen terendah terdapat pada perlakuan $\mathrm{R}_{1}$ sebesar $53,9374 \%$. Perbedaan dari nitrogen yang diretensi tersebut merupakan dampak awal dari pengaruh perbedaan cara pengolahan tepung ikan dari limbah industri pengolahan ikan nila. Ayam kampung yang diberi tepung ikan komersial meretensi nitrogen lebih tinggi dibandingkan dengan ayam kampung yang diberikan tepung ikan LIPIN yang mengalami pengolahan terutama pada pengolahan melalui pengeringan oven dan dipres sebelum perlakuan.

Analisis keragaman retensi nitrogen menunjukkan bahwa perbedaan pengolahan tepung ikan memberikan pengaruh yang sangat berbeda nyata terhadap retensi nitrogen. Perbedaan dari masing-masing perlakuan dapat dilihat jelas pada uji ortogonal kontras. Untuk melihat informasi perlakuan tertinggi dan terendah disajikan pada Tabel 2.

Tabel 2. Rekapitulasi hasil Penelitian

\begin{tabular}{lcccccc}
\hline Perlakuan & $\begin{array}{c}\text { Retensi } \\
\text { Nitrogen }\end{array}$ & EMs & EMm & EMMs & EMMm & $\begin{array}{c}\text { Konversi } \\
\text { Energi }\end{array}$ \\
\hline R0 & $83,36 \pm 1,97$ & $1673,70 \pm 58,75$ & $2195,49 \pm 58,75$ & $1673,37 \pm 58,74$ & $2195,15 \pm 58,74$ & $0,86 \pm 0,03$ \\
R1 & $53,93 \pm 7,44$ & $2597,61 \pm 416,65$ & $3119,39 \pm 416,65$ & $2597,39 \pm 416,61$ & $3119,17 \pm 416,6$ & $0,63 \pm 0,10$ \\
R2 & $60,40 \pm 7,69$ & $2502,82 \pm 289,83$ & $3024,61 \pm 289,83$ & $2502,57 \pm 289,79$ & $3024,35 \pm 289,79$ & $0,71 \pm 0,08$ \\
R3 & $57,95 \pm 5,29$ & $3108,40 \pm 127,81$ & $3630,19 \pm 127,81$ & $3108,16 \pm 127,80$ & $3629,94 \pm 127,80$ & $0,73 \pm 0,03$ \\
R4 & $62,11 \pm 11,12$ & $3000,54 \pm 402,65$ & $3522,32 \pm 402,65$ & $3000,27 \pm 402,60$ & $3522,06 \pm 402,60$ & $0,73 \pm 0,09$ \\
R5 & $59,12 \pm 7,22$ & $4620,57 \pm 500,47$ & $5142,35 \pm 500,47$ & $4620,32 \pm 500,44$ & $5142,10 \pm \pm 500,44$ & $0,77 \pm 0,08$ \\
\hline
\end{tabular}

Uji ortogonal kontras menunjukkan bahwa perlakuan R0 tepung ikan komersial sangat berbeda nyata lebih tinggi $(\mathrm{P}<0,01)$ dibandingkan dengan perlakuan $\mathrm{R} 1, \mathrm{R} 2, \mathrm{R} 3, \mathrm{R} 4$ dan R5 yaitu tepung ikan dengan oven dipres, matahari dipres, oven tanpa pres, matahari pres dan silase fermentasi. Hal ini disebabkan karena kandungan protein dari tepung ikan komersial lebih tinggi dari limbah pengolahan ikan nila dibuktikan dengan analisis kimia laboratorium dan juga komponen penyusun perlakuan R0 berupa daging dengan kandungan protein tinggi, sedangkan perlakuan R1, R2, R3, R4 dan R5dari tulang dan hanya sedikit 
daging. Hal ini sesuai dengan pernyataan dari Amrullah (2003) yang menyatakan bahwa jumlah energi yang dapat dimanfaatkan sewaktu ransum masuk ke tubuh unggas bergantung pada komposisi bahan makanan dan zat makanan dalam ransum, spesies, faktor genetis, umur unggas, juga kondisi lingkungan.

Uji ortogonal kontras menunjukkan perlakuan tepung ikan dipres (R12) memberikan pengaruh yang tidak nyata $(\mathrm{P}>0,01)$ terhadap perlakuan tepung ikan tanpa pres (R34). Hal ini disebabkan karena tepung ikan yang dipres menurunkan kadar air menjadi $50 \%$ dan kadar minyak 4-5\% sedangkan perlakuan dengan tanpa pres menyebabkan kadar minyak tinggi dan airnya juga tinggi sehingga mudah diserang serangga dan jamur dan mempengaruhi kandungan protein didalam tepung ikan tersebut. Hal ini sesuai dengan pernyataan dari Saleh (1990) yang menyatakan bahwa tepung ikan yang tidak dipres menjadi kotor dan pengeluaran air menjadi tidak sempurna serta mudah diserang serangga, jamur karena kadar air dan lemak masih tinggi.

Dalam pembanding ortogonal kontras perlakuan dengansumber pengeringan yang berbeda antara pengeringan oven (R13) memberikan pengaruh yang sangat berbeda nyata lebih rendah $(\mathrm{P}<0,01)$ dengan pengeringan matahari $\mathrm{R} 24$. Hal ini karena pada pengeringan oven dengan suhu $400 \mathrm{C}$ tidak merusak kandungan nutrisi pada tepung ikan karena suhunya tetap sedangkan pada pengeringan matahari mempengaruhi kandungan nutrisinya karena suhu matahari tidak stabil atau sewaktu waktu berubah. Hal ini sesuai dengan pernyataan dari Sunarya (1998) yang menyatakan bahwa cara pengeringan tidak langsung dengan memanaskan bahan yang dipres dengan uap panas harus mencapai 6-9\%, sedangkan pada industri kecil, pengeringan dilakukan dengan sinar matahari.

Uji pembanding ortogonal kontras tepung ikan komersial (R0) memberikan pengaruh yang sangat berbeda nyata lebih tinggi $(\mathrm{P}<0,01)$ terhadap tepung ikan dengan silase fermentasi (R5). Perbedaan ini disebabkan karena tepung ikan komersial komponen penyusunnya berupa daging dengan kandungan protein tinggi, sedangkan pada perlakuan silase yang difermentasikan berupa tulang dan hanya sedikit daging segar yang melekat pada tulang ikan dan pada proses fermentasi yang berlangsung tersebut menurunkan nilai $\mathrm{pH}$ dan hanya berfungsi sebagai bahan pengawet silase ikan tersebut. Adapun hal ini sesuai dengan pernyataan dari Kompiang (1980), yang menyatakan bahwa pada pembuatan silase biologi, bakteri akan memfermentasikan gula sehingga terbentuk asam laktat yang dapat menurunkan nilai $\mathrm{pH}$ dan berfungsi sebagai bahan pengawet silasi ikan itu. 
Tabel 3. Uji Ortogonal Kontras

\begin{tabular}{|c|c|c|c|c|c|c|c|c|}
\hline Sv & Fhit RN & Fhit EMs & Fhit EMm & Fhit EMMs & Fhit EMMm & \multicolumn{2}{|c|}{$\begin{array}{c}\text { Fhit } \\
\text { Konversi }\end{array}$} & \multicolumn{2}{|c|}{ F tabel } \\
\hline Perlakuan & $8.10^{* *}$ & $33,14^{* *}$ & $33,14^{* *}$ & $33,15^{* *}$ & $33,15^{* *}$ & $3,89^{*}$ & 0,05 & 0,01 \\
\hline R0 VS R12345 & $154.70^{* *}$ & $264,81^{* *}$ & $264,81^{* *}$ & $264,89^{* *}$ & $264,89^{* *}$ & $49,65^{* *}$ & 2,77 & 4,25 \\
\hline R12 VS R34 & $2.44^{\text {tn }}$ & $35,37^{* *}$ & $35,37^{* *}$ & $35,38^{* *}$ & $35,38^{* *}$ & $11,44^{* *}$ & 4,41 & 8,28 \\
\hline R13 VS R24 & $8,40^{* *}$ & $0,62^{\text {tn }}$ & $1,42^{\text {tn }}$ & $1,42^{\text {tn }}$ & $1,42^{\text {tn }}$ & $4,00^{\text {tn }}$ & 4,41 & 8,28 \\
\hline R0 VS R5 & $139.91^{* *}$ & $25,51^{* *}$ & $966.56^{* *}$ & $966,80^{* *}$ & $966,80^{* *}$ & $17.99^{* *}$ & 4,41 & 8,28 \\
\hline R1234 VS R5 & $0.16^{\text {tn }}$ & $919,91^{* *}$ & $919,91^{* *}$ & $920,08^{* *}$ & $920,08^{* *}$ & $25,92^{* *}$ & 4,41 & 8,28 \\
\hline
\end{tabular}

Ket :

$$
\begin{array}{ll}
\text { tn } & : \text { tidak nyata } \\
* & : \text { berbeda nyata } \\
* * & : \text { berbeda sangat nyata }
\end{array}
$$

Hasil uji orthogonal kontras perlakuan oven dipres maupun tanpa dipres dan matahari dipres maupun tanpa pres (R1234) menunjukan pengaruh yang tidak nyata $(\mathrm{P}>0,01)$ terhadap perlakuan silase fermentasi R5. Hal ini disebabkan karena pada perlakuan R1234 dengan pengolahan pres dan tanpa pres baik pengeringan secara oven maupun matahari tidak merubah kandungan proteinnya sedangkan pada silase perlakuan fermentasi yang diberikan hanya menurunkan $\mathrm{pH}$ dan berfungsi sebagai bahan pengawet.

\section{Energi Metabolisme}

Perhitungan energi metabolisme dinyatakan dengan 4 peubah yaitu energi metabolisme semu, energi metabolisme murni, energi metabolisme semu terkoreksi nitrogen dan energi metabolisme murni terkoreksi nitrogen. Energi metabolisme murni (EMM) merupakan energi metabolisme yangmemperhitungkan energi endogenous sebagai faktor koreksi (Sibbald, 1980). Hal ini menyebabkan nilai dari EMM lebih besar dari EMS. Energi endogenous terdiri dari metabolic faecal dan endogenous urinary yang berasal dari katabolisme jaringan tubuh untuk kebutuhan hidup pokok pada saat dipuasakan dan sebagian lagi berasal dari produk akhir yang mengandung nitrogen (Wolynetz dan Sibbald, 1985). EMS tidak memperhitungkan metabolic faecal dan endogenous urinary (Sibbald, 1989). Rataan Rataan energi metabolisme semu dan murni dapat dilihat pada Tabel 2.

Pada Tabel 2 menunjukkan bahwa energi metabolisme semu dan murni tertinggi terdapat pada perlakuan R5 yaitu tepung ikan silase fermentasi sebesar 4620,5720 kkal/kg dan 5142,3575 kkal/kg. Energi semu dan murni terendah terdapat pada perlakuan R0 yaitu sebesar 1673,7093 kkal/kg dan 2195,4948 kkal/kg. Hal ini menunjukkan bahwa proses fermentasi sangat berpengaruh dalam metabolisme tepung ikan oleh ayam kampung.

Analisis sidik ragam energi metabolisme semu dan murni menunjukkan bahwa pengaruh perbedaan cara pengolahan tepung ikan LIPIN memberikan pengaruh yang sangat 
berbeda nyata pada ayam kampung. Setelah dilakukan uji ortogonal kontras dapat dilihat informasi perlakuan yang terbaik energi metabolisme semu dan murni disajikan pada Tabel 3.

Pada tabel menunjukkan uji pembandingan ortogonal kontras energi metabolisme semu dan murni perlakuantepung ikan komersial (R0)sangat berbeda nyata lebih rendah $(\mathrm{P}<0,01)$ dengan perlakuan R1, R2, R3, R4 dan R5 yaitu tepung ikan dengan oven dipres, matahari dipres, oven tanpa pres, matahari tanpa pres dan silase fermentasi. Perbedaan ini karena pada perlakuan R0 yang tanpa melalui perlakuan apapun sehingga tidak mengganggu komponen penyusun tepung ikannya yaitu berupa daging dengan kandungan protein tinggi dibandingkan dengan R12345 dengan berbagai metode pengolahan yang mempengaruhi kandungan protein dan lemak dalam tepung ikan tersebut. Hal ini sesuai dengan pernyataan dari Sibbald (1976), yang menyatakan bahwa penentuan energi bruto bahan pakan yaitu dengan mengukur energi bruto feses dan energi bruto endogenous serta dapat mengetahui nilai energi metabolisme murni (EMM).

Hasil uji ortogonal kontras energi metabolisme semu dan murni dari perlakuan tepung ikan dipres (R12) memberikan pengaruh yang sangat berbeda nyata lebih rendah $(\mathrm{P}<0,01)$ terhadap perlakuan tepung ikan tanpa pres (R34). Perbedaan ini karena pada perlakuan R12 kadar lemaknya lebih rendah akibat dari proses pengepresan minyak yang dilakukan dibandingkan dengan perlakuan R34 yang kadar lemaknya tinggi karena tidak mengalami proses pengepresan.

Pada perlakuan dengan sumber pengeringan yang berbeda, pengeringan oven (R13) menunjukan pengaruh yang tidak nyata $(\mathrm{P}>0,01)$ terhadap pengeringan dengan matahari (R24). Hal ini dikarenakan sumber pengeringan yang berbeda baik secara oven maupun matahari relatif stabil sehingga tidak mempengaruhi total energi metabolisme terhadap perlakuan tersebut.

Uji ortogonal kontras energi metabolisme semu dan murni dari perlakuan tepung ikan komersial (R0) memberikan pengaruh yang sangat berbeda nyata lebih rendah $(\mathrm{P}<0,01)$ terhadap perlakuan R5 yakni pakan secara silase fermentasi. Hal ini karena pada perlakuan R0 tidak mengalami metode pengolahan sehingga tidak mengganggu susunan atau kandungan protein dan lemak didalam tepung ikan tersebut dibandingkan dengan perlakuan R5 dengan metode tepung ikan difermentasi dengan tujuan untuk meningkatkan kandungan protein yang terkandung didalam tepung ikan tersebut, sehingga nilai energi metabolisme diantara keduanya berbeda.

Uji pembanding ortogonal kontras energi metabolisme semu dan murni dari perlakuan tepung ikan yang dipres dan tidak dipres baik dari sumber pengeringan oven dan matahari 
(R1234) menunjukan pengaruh yang sangat berbeda nyata lebih rendah $(\mathrm{P}<0,01)$ terhadap perlakuan tepung ikan secara silase fermentasi (R5). Adapun hal ini disebabkan oleh metode pengolahan yang berbeda-beda berpengaruh meningkatkan ataupun menurunkan kandungan protein maupun kadar lemak tepung ikan dibandingkan dengan R5 yang ditambahkan bakteri yang membentuk asam laktat sebagai bahan pengawet silase ikan tersebut. Hal ini sesuai dengan pernyataan dari ahlli yakni Storey dan Allen (1982), yang menyatakan bahwa nilai energi metabolisme dipengaruhi oleh kandungan energi bruto dalam pakan atau ransum tersebut, jumlah pakan atau ransum yang dikonsumsi, dan juga jenis ternak, serta juga dipengaruhi oleh kemampuan ternak untuk memetabolis pakan atau ransum atau bahan pakan didalam tubuhnya.

Nilai energi metabolisme semu terkoreksi nitrogen (EMSn) dan energi metabolisme murni terkoreksi nitrogen (EMMn) merupakan nilai energi metabolis yang dikoreksi dengan nitrogen, sehingga nilainya lebih kecil dari EMS dan EMM. Rataan energi metabolisme terkoreksi nitrogen disajikan ada Tabel 2.

Pada Tabel 2 menunjukkan bahwa energi metabolisme semu dan murni terkoreksi nitrogen tertinggi terdapat pada perlakuan R5 yaitu tepung ikan silase fermentasi sebesar $4620,3216 \mathrm{kkal} / \mathrm{kg}$ dan 5142,1071kkal/kg. Energi semu dan murni terkoreksi nitrogen terendah terdapat pada perlakuan R0 yaitu sebesar $1673,3716 \mathrm{kkal} / \mathrm{kg}$ dan $2195,1571 \mathrm{kkal} / \mathrm{kg}$. Hal ini menunjukkan bahwa pengolahan pada tepung ikan LIPIN terutama dengan proses fermentasi sangat berpengaruh dalam metabolisme ayam kampung.

Daya cerna terhadap tepung ikan yang tinggi ditunjukan dari tingginya nitrogen yang diretensi.Retensi nitrogen yang tinggi ini menunjukan bahwa tingkat konsumsi energi ayam yang tinggi pula.Konsumsi energi yang tinggi tersebut memberikan gambaran bahwasanya tingkat energi metabolisme yang tinggi. Hal ini sesuai dengan pendapat Storey dan Allen (1982), yang menyatakan bahwa semakin tinggi konsumsi energinya, maka energi metabolis semakin tinggi.

Analisis sidik ragam energi metabolisme semu dan murni menunjukkan bahwa pengaruh perbedaan cara pengolahan tepung ikan LIPIN memberikan pengaruh yang sangat berbeda nyata.Uji pembandingan ortogonal kontras untuk energi metabolisme semu terkoreksi nitrogen (EMSn) dan energi metabolisme murni terkoreksi nitrogen (EMMn) dapat dilihat pada tabel 3 .

Hasil pembanding uji ortogonal kontras energi metabolisme semu terkoreksi nitrogen (EMSn) dan murni terkoreksi nitrogen (EMMn) diatas menunjukkan bahwa terdapat perbedaan yang sangat berbeda nyata lebih rendah $(\mathrm{P}<0,01)$ antara setiap pembandingan 
ortogonal kontras kecuali pada pembandingan antara tepung ikan yang diolah dengan sumber pengeringan yang berbeda (R13 vs R24). Hasil penelitian ini menunjukkan bahwa ayam dengan penampilan akhir yang baik memberikan gambaran bahwa tingkat energi metabolismenya yang semakin tinggi. Nilai energi metabolisme semu terkoreksi nitrogen (EMSn) dan energi metabolisme murni terkoreksi nitrogen EMMn yang lebih rendah dari energi metabolisme semu (EMS)dan energi metabolisme murni (EMM) pada teknik force feeding disebabkan oleh adanya faktor koreksi nitrogen yang diretensi tubuh. Menurut McDonald et al. (2002) dalam penentuan energi metabolis perlu dikoreksi terhadap jumlah nitrogen yang diretensi, karena kemampuan ternak dalam memanfaatkan energi bruto dari protein kasar sangat bervariasi.Selanjutnya NRC (1994) menjelaskan bahwa semakin bertambah umur dan bobot badan ternak, maka energi metabolisnya akan semakin tinggi.

\section{Konversi EMSn/EB}

Daya cerna energi bukan ditentukan oleh nilai energi metabolisme baik semu (EMS), murni (EMM), semu terkoreksi nitrogen (EMSn) ataupun murni terkoreksi nitrogen (EMMn), akan tetapi ditentukan oleh konversi EMSn terhadap energi bruto atau rasio EM/EB tepung ikan. Nilai konversi EMSn terhadap energi bruto tepung ikan perlakuan disajikan pada tabel 2.

Rasio EMSn/EB tepung ikan tertinggi pada penelitian ini diperoleh pada perlakuan Ro sebesar 0,8675 dan rasio EMSn/EB tepung ikan terendah pada penelitian ini diperoleh dari ayam kampung dengan perlakuan R1 yaitu sebesar 0,6354. Hasil sidik ragam menunjukkan bahwa perbedaan cara pengolahan tepung ikan LIPIN memberikan pengaruh yang berbeda nyata dalam mempengaruhi konversi EMSn terhadap energi bruto tepung ikan. Hal ini dapat diartikan bahwa ayam kampung yang diberikan tepung ikan yang berbeda cara pengolahannya mempengaruhi efisiensi penggunaan energi bruto menjadi energi metabolis dibandingkan dengan tepung ikan komersial. Perbedaan nilai konversi terbaik dapat dilihat pada tabel 3.

Hasil uji ortogonal kontras perlakuan tepung ikan komersial (R0) memberikan pengaruh yang sangat berbeda nyata lebih tinggi $(\mathrm{P}<0,01)$ terhadap perlakuan $\mathrm{R} 1, \mathrm{R} 2, \mathrm{R} 3, \mathrm{R} 4$ dan R5 yaitu tepung ikan dengan oven dipres, matahari dipres, oven tanpa pres, matahari tanpa pres dan silase fermentasi. Hal ini disebabkan karena perlakuan tepung ikan komersial R0 dengan komponen penyusun lebih banyak daging dan proteinnya juga tinggi dibandingkan perlakuan lain yang telah dipres dengan kadar lemaknya diangkat maupun 
dengan tepung ikan yang difermentasikan sehingga penggunan energi bruto menjadi energi metabolis dapat semaksimal mungkin.

Uji ortogonal kontras konversi energi diatas menunjukan perlakuan tepung ikan dengan dipres (R12) memberikan pengaruh yang sangat berbeda nyata lebih rendah $(\mathrm{P}<0,01)$ terhadap perlakuan tepung ikan tanpa dipres R34. Perbedaan ini karena perlakuan tepung ikan dipres (R12) menurunkan kadar air menjadi 50\% dan kadar minyak 4-5\% sedangkan perlakuan dengan tanpa pres menyebabkan kadar minyak tinggi dan airnya juga tinggi sehingga mudah diserang serangga dan jamur dan mempengaruhi kandungan protein didalam tepung ikan tersebut, sehingga mempengaruhi penggunan energi bruto menjadi energi metabolis tidak maksimal. Hal ini sesuai dengan pernyataan dari Saleh (1990), yang menyatakan bahwa pengepresan yang dilakukan dengan tidak baik menyebabkan kadar air dan lemak masih tinggi, warna dan bau akan cepat berubah sehingga mutu tepung ikan akan cepat turun.

Perlakuan tepung ikan dengan sumber pengeringan oven (R13) memberikan pengaruh yangtidak berbeda nyataterhadap perlakuan tepung ikan dengan pengeringan matahari (R24). Hal ini disebabkan karena pengeringan dengan sumber panas yang berbeda baik oven dan matahari yang relatif stabil tidak terlalu signifikan berpengaruh terhadap nilai energi metabolisme untuk konversi energi.

Perlakuan tepung ikan komersial R0 memberikan pengaruh sangat berbeda nyata lebih tinggi $(\mathrm{P}<0,01)$ terhadap perlakuan tepung ikan silase fermentasi Perbedaan ini disebabkan karena tepung ikan komersial komponen penyusunnya berupa daging dengan kandungan protein tinggi, sedangkan pada perlakuan silase yang difermentasikan berupa tulang dan hanya sedikit daging segar yang melekat pada tulang ikan dan pada proses fermentasi yang berlangsung tersebut menurunkan nilai $\mathrm{pH}$ dan hanya berfungsi sebagai bahan pengawet silase ikan tersebut. Adapun hal ini sesuai dengan pernyataan dari Kompiang (1980), yang menyatakan bahwa pada pembuatan silase biologi, bakteri akan memfermentasikan gula sehingga terbentuk asam laktat yang dapat menurunkan nilai $\mathrm{pH}$ dan berfungsi sebagai bahan pengawet silasi ikan itu.

Hasil uji ortogonal kontras menunjukkan bahwa perlakuan tepung ikan yang dipres dan tidak dipres baik dari sumber pengeringan oven dan matahari (R1234) menunjukan pengaruh yang sangat berbeda nyata lebih rendah $(\mathrm{P}<0,01)$ terhadap perlakuan tepung ikan secara silase fermentasi (R5). Adapun hal ini disebabkan karena perlakuan dengan berbagai metode R1234 tidak mengganggu kandungan protein yang terkandung didalam tepung ikan dibanding dengan silase yang difermentasi dengan memfermentasikan gula sehingga 
terbentuk asam laktat yang dapat menurunkan nilai $\mathrm{pH}$ dan berfungsi sebagai bahan pengawet silase ikan tersebut.

Pemberian tepung ikan komersial R0 merupakan perlakuan yang sangat efisien karena ayam kampung dapat menggunakan energi bruto menjadi energi metabolis semaksimal mungkin, kemudian diikuti oleh perlakuan R5 yaitu tepung ikan dengan pengolahan fermentasi menggunakan energi bruto menjadi energi metabolis dengan baik sehingga diperoleh nilai konversi yang cukup tinggi. Angka ini menunjukkan bahwa tepung ikan komersial memiliki nilai konversi lebih tinggi. Hal ini disebabkan karena tepung ikan komersial berasal dari ikan utuh yg diproses menjadi tepung sehingga mengandung kadar protein yang tinggi dibandingkan dengan perlakuan lainnya yang terdiri dari hanya sedikit daging dan kebanyakan tulang, dimana tulang tersebut lebih banyak mengandung mineral dibandingkan protein. Adapun hal ini juga dipengaruhi oleh tingkat perkembangan saluran pencernaan ayam kampung yang lebih baik dan juga struktur tepung ikan yang sudah lebih mudah dicerna melalui cara pengolahan yang berbeda. Hal ini sesuai dengan pernyataan Amrullah (2003) menyatakan bahwa jumlah energi yang dapat dimanfaatkan sewaktu ransum masuk ke tubuh unggas bergantung pada besar kecilnya kapasitas tampung organ pencernaan unggas. Dilanjutkan dengan pernyataan Wahju (1985) yang menyatakan bahwa ternak umumnya memperoleh energi dari pakan yang dikonsumsi. Akan tetapi tidak semua energi pakan tersebut dapat digunakan oleh tubuh ternak. Energi bruto yang terdapat pada masingmasing tepung ikan mempengaruhi besarnya nilai konversi. Penggunaan energi pakan untuk tubuh unggas sangat penting untuk diketahui terutama untuk memenuhi kebutuhannya sesuai dengan tujuan pemeliharaan. Hal ini lebih penting lagi karena tidak semua bahan pakan yang mempunyai energi bruto yang sama mempunyai daya guna yang sama.

\section{KESIMPULAN}

Tepung ikan komersial menunjukan hasil retensi nitrogen dan konversi energi lebih tinggi, tetapi energi metabolisme lebih rendah dibandingkan dengan LIPIN. Tepung ikan dipres menunjukan hasil retensi nitrogen, energi metabolisme dan konversi energi lebih rendah dibandingkan dengan tepung ikan tanpa dipres. Tepung ikan pengeringan oven dipres dan tanpa dipres, menunjukan hasil energi metabolisme lebih tinggi tetapi retensi nitrogen dan konversi energi lebih rendah dibandingkan dengan tepung ikan pengeringan matahari dipres dan tanpa dipres. Tepung ikan LIPIN menunjukan hasil retensi nitrogen energi metabolisme dan konversi energi lebih rendah dibandingkan dengan silase fermentasi. 
Tepung ikan komersial menunjukan hasil retensi nitrogen dan konversi energi lebih tinggi tetapi energi metabolisme lebih rendah dibandingkan dengan silase fermentasi. Limbah industri pengolahan ikan nila (LIPIN) potensial digunakan untuk menggantikan tepung ikan komersial sebagai pakan ternak ayam kampung.

\section{DAFTAR PUSTAKA}

Amrullah, I. K. 2003. Nutrisi Ayam. Lembaga Satu Gunung Budi, Bogor.

Boniran, S, 1999. Kualitas Kontrol Untuk Bahan Baku dan Produk Akhir Pakan Ternak. Kumpulan Makanan Quality Management Workshop.

Kompiang, I.P. 1980. Penggunaan Tepung Silase Ikan. Prosiding Rapat Teknis Tepung Ikan. Pusat Penelitian dan Pengembangan Pertanian. Badan Penelitian dan Pengembangan Pertanian. Departemen Pertanian, Jakarta.

McDonald, P., R.A. Edwards, J. F. D. Greenhalgh and C. A. Morgan. 2002. Animal Nutrition $6^{\text {th }}$ Ed. Longmann Singapore Pubishers (Pte) Ltd.

National Research Council. 1994. Nutrient Requirement of Poultry. $9^{\text {th }}$ Revised Edition. National Academy of Science. Washington D. C. USA.

Saleh, M. 1990. Pengaruh Pengepresan, Mutu Bahan Mentah dan Penyimpanan Terhadap Mutu Tepung Ikan. Jurnal Penelitian Pasca Panen Perikanan No. 65 Balai Perikanan Laut. Departemen Pertanian, Jakarta.

Sastrosupadi, 2002. Matematik Rancangan Percobaan. Penebar Swadaya, Jakarta.

Sibbald, I. R. 1976. A Bioassay for True Metabolizable Energy in Feedingstuffs. Poultry Sci., $55:$ 303-305.

Sibbald, I. R. 1980. Metabolic Plus Endogenous Energy and Nitrogen Losses of Adult Cockerels: The Correction Used in Bioassay for True Metabolizable Energy. Poultry Sci. 60 : 805-811.

Sibbald, I. R. and M. S. Wolynetz. 1985. Estimates of Retained Nitrogen Used to Correct Estimates of Bioavailable Energy. Poultry Sci., 64 : 1506-1513.

Storey, M. L.and N. K. Allen. 1982. Apparent and True Metabolizable Energy of Feedingstuffs For Manure, Non Laying Female Ambden Geese. Poultry Sci. 60 : 739747.

Sunarya. 1998. Pengembangan Tepung Ikan di Indonesia. Penebar Swadaya, Jakarta.

Wahju, J. 1985. Ilmu Nutrisi Unggas. Gadjah Mada University Press, Yogyakarta. 